\title{
Amplification and clinicopathological significance of HER-2 in Kazakh esophageal squamous cell carcinoma
}

\author{
AISHANJIANG MUHETAER ${ }^{1,2}$, MADINIYET NIYAZ $^{3}$, JULAITI AINIWAER $^{1}$, ZHANG LIWEI $^{1}$ and EDRIS AWUT ${ }^{1}$ \\ ${ }^{1}$ Department of Thoracic Surgery, First Affiliated Hospital of Xinjiang Medical University, Urumqi, Xinjiang 830054; \\ ${ }^{2}$ Thoracic Surgery, Kashi First People's Hospital, Kashi, Xinjiang 844000; \\ ${ }^{3}$ First Affiliated Hospital/Clinical Medicine Research Institute of Xinjiang \\ Medical University, Urumqi, Xinjiang 830054, P.R. China
}

Received December 23, 2019; Accepted August 25, 2020

DOI: $10.3892 / \mathrm{mco} .2020 .2134$

\begin{abstract}
Amplification and overexpression of the human epidermal growth factor receptor-2 (HER-2) gene accelerates cell division and proliferation, and promotes tumor growth and metastasis in various malignant tumors. However, there are few reports on its influence and mechanism in esophageal cancer. The aim of the present study was to investigate the gene amplification and clinicopathological significance of HER-2 in Kazakh esophageal squamous cell carcinoma (ESCC). HER-2 gene amplification was detected in 70 esophageal cancer tissues using fluorescence in situ hybridization. The association between the HER-2 gene amplification and the clinicopathological characteristics of patients with esophageal cancer was also analyzed. The amplification rate of the HER-2 gene in patients with esophageal cancer was 54.2\% (38/70). The results also revealed a positive association between the amplification rate of the HER-2 gene in esophageal squamous cell carcinomas and the level of tissue differentiation, increasing gradually and significantly among the highly, moderately and poorly differentiated tissues $(\mathrm{P}<0.05)$. The amplification rate of the HER-2 gene in patients with lymph node metastasis was higher than those without $(\mathrm{P}<0.05)$. There was no significant association between the amplification rate of the HER-2 gene and any of the clinic pathological parameters, such as sex, age, depth of invasion and 3-year survival, among patients $(\mathrm{P}>0.05)$. In conclusion, the amplification rate of the HER-2 gene in patients with Kazakh ESCC was high. There was an association with various prognostic factors, including cancer differentiation and lymph node metastasis. HER-2 gene expression levels may be considered as an indicator of
\end{abstract}

Correspondence to: Professor Edris Awut, Department of Thoracic Surgery, First Affiliated Hospital of Xinjiang Medical University, 137 Liyushan South Road, Urumqi, Xinjiang 830054, P.R. China

E-mail: 15999180777@qq.com

Key words: Kazakh, esophageal squamous cell carcinoma, human epidermal growth factor receptor-2 gene, fluorescence in situ hybridization poor prognosis in patients with ESCC in the clinical setting, and this may provide a basis of treatment for individualized targeted therapies.

\section{Introduction}

Esophageal cancer is one of the highly malignant tumors worldwide. The incidence rate and the mortality rate rank 6 th and 4th among all cancers in China, respectively (1), 95\% of all esophageal cancer cases are cases of squamous cell carcinoma (2). There are regional and ethnic variations in the incidence rate and etiological factors behind esophageal cancer. The variation between different nationalities and geographical regions are likely to be related to genetic susceptibility (3). Xinjiang is a multi-ethnic residential area and is an area with high incidence for esophageal cancer, and Kazakh populations present the highest risk of esophageal cancer in the area. The prognosis of esophageal cancer types has been improved by surgery, chemotherapy, radiotherapy, targeted therapy and immunotherapy; however, the prognosis is still unsatisfactory. The overall 5-year survival rate is less than $20 \%$ (4). Therefore, early diagnosis, early treatment and new treatment methods are needed to improve the recovery rate and the 5-year survival rate. Targeted therapy is an important step in the development of individualized treatment in for patients with esophageal cancer.

Human epidermal growth factor receptor-2 (HER-2) is a member of the epidermal growth factor receptor (EGFR) family, and it is a transmembrane tyrosine kinase receptor with a molecular weight of $185 \mathrm{kDa}$. Overexpression of the HER-2 protein in malignant tumor cells accelerates cell division and proliferation, and ultimately promotes tumor growth and metastasis (5). In recent years, HER-2 receptors and the whole HER-2-mediated signaling pathway have been identified as targets in the treatment of various malignant tumors (6).

Fluorescence in situ hybridization (FISH) is a molecular pathological technique used to detect chromosome aberration, gene deletion and amplification by using special fluorescent labeled DNA single-stranded-nucleates as probes. It is widely used in the detection of various cancers such as leukemia, lung cancer, breast cancer and renal cancer. Due to its high sensitivity and specificity, it can qualitatively detect malignant cells $(7,8)$. FISH is recognized as the gold standard for detecting the HER-2 
gene (9). There are significant regional and ethnic variations in esophageal cancer rates worldwide; however, there is currently no reports on the HER-2 gene of Kazakh patients with esophageal cancer. Thus, the current study detected HER-2 gene amplification in esophageal squamous cell carcinoma (ESCC) tissues, and analyzed the association between HER-2 gene amplification and the clinicopathological characteristics of ESCC patients. This is to provide a theoretical basis for the research, diagnosis and treatment of ESCC patients in Kazakh populations, to explore the association between HER-2 gene amplification and the survival period of patients with esophageal cancer after radical operation, and to evaluate the association between HER-2 gene expression levels and the prognosis of patients with ESCC.

\section{Patients and methods}

Patients. A total of 70 specimens were obtained from Kazakh patients who had not received chemotherapy or radiotherapy prior to surgery from the Department of Thoracic Surgery of the First Affiliated Hospital of Xinjiang Medical University, China, from January 2014 to January 2016. There were 54 males and 16 females, with a median age of 55.5 years (range of 32-79 years). Postoperative pathological diagnosis was confirmed as ESCC, and according to the 7th edition of AJCC Cancer Staging Manual (10), 17 cases were poorly differentiated, 39 cases were moderately differentiated and 14 cases were highly differentiated. There were 41 cases of positive lymph node metastasis vs. 29 cases of negative lymph node metastasis; 7 cases had IA-IB stage, 39 had IIA-IIB stage and 24 had IIIA-IIIB stage disease. All patients undergoing surgery had written consent to use their tissues for this study. The collection of samples conformed to the ethical requirements and this study was approved by the Ethics Committee of the First Affiliated Hospital of Xinjiang Medical University.

FISH and score for HER-2/neu. FISH analysis was performed in the Department of Pathology of the First Affiliated Hospital of Xinjiang Medical University, using the PathVysion HER-2/neu (Vysis) kit composed of 2 hybridization probes: A DNA probe CEP17 of $5.4 \mathrm{~kb}$ for the centromeric region of chromosome 17, marked with Spectrum Green and a DNA locus-specific probe LSI HER2/neu of $190 \mathrm{~Kb}$, marked with Spectrum Orange for HER2/neu.

Fresh cancer tissue was applied to the slide and was dried at room temperature $\left(25^{\circ} \mathrm{C}\right)$ for $24 \mathrm{~h}$, then was preserved at $-80^{\circ} \mathrm{C}$. After decomposition and denaturation with $70 \%$ formamide solution, specimens were dehydrated in 70,85 and $100 \%$ ethanol series. The ThermoBrite automatic in situ hybridization system was used, the hybridization conditions were as follows: Denaturation at $75^{\circ} \mathrm{C}$ for $5 \mathrm{~min}$, hybridization at $37^{\circ} \mathrm{C}$ for $16 \mathrm{~h}$. The next day, slides were washed with $2 x \mathrm{SSC}$ solution for $2 \mathrm{~min}$ at $72^{\circ} \mathrm{C}$ and then at room temperature for $1 \mathrm{~min}$. Slides were allowed to dry in the dark. After the slides were dried, $10 \mu$ l DAPI II was added and the glass was covered. Ultimately this was observed using fluorescence microscopy.

A special image acquisition and analysis system (Leica Microsystems, Ltd.) was used to count the number of signals under a fluorescence microscope. The counting results were independently completed by two participants, and the results were confirmed only when the counts were consistent.
Results criteria: At least 100 nuclei were counted. When the ratio of red signal (HER2-neu) to green signal (17 chromosome centromere) was $\geq 2.0$, or the number of nuclei of cells with $>15$ red signals for $>10 \%$ of the total number of cells, HER2-neu was considered to be amplified. When the ratio of red signal to green signal was less than 1.8, HER2-neu was considered to not be amplified; if the ratio of red signal to green signal was between 1.8 and 2.0, a total of 100 extra cells were counted (11).

Statistical analysis. For statistical analysis a $\chi^{2}$ test was used to evaluate the differences between the two groups, the survival analysis was performed by the Kaplan-Meier with log-rank test, and in all tests $\mathrm{P}<0.05$ was considered to indicate a statistically significant difference. Statistical calculations were performed using SPSS 20.0 (IBM Corp.).

\section{Results}

HER2 amplification pattern. The FISH technique was used to detect HER-2 gene expression levels in 87 fresh specimens of ESCC. Among them, results from 70 cases were recorded, with the remaining 17 being excluded due to failure of the experiment, nuclear rupture and unclear nuclear staining. In the current study, the positive amplification rate of HER-2 was 54.2\% (38/70). Normal epithelial cells and non-neoplastic stroma or inflammatory cells generally presented two HER-2 signals. There were two patterns observed in the HER-2 gene amplification in esophageal cancer samples of Kazakh populations: $>15$ red signals (HER-2) and multiple green signals (CEP17) in $>10 \%$ of tumor cell nucleus were amplified, and $\geq 4$ red signals (HER-2) and green signals (CEP17) in $>40 \%$ of the tumor cells that showed as polysomy, were amplified (HER2/CEP17 ratio $\geq 2.0$, Table I and Fig. 1).

Association between HER2 gene amplification and clinicopathological characteristics. The amplification rates of the HER-2 gene were 14\% (2/14), 54\% (21/39) and 88\% (15/17) among the highly differentiated, moderately differentiated and in poorly differentiated groups, respectively. Statistical differences were observed in different degrees of differentiations $(\mathrm{P}<0.001)$. The amplification rate of the HER-2 gene in the lymph node metastasis group was higher than that of the non-lymph node metastasis group $(\mathrm{P}<0.010)$; However, there were no significant differences in the HER-2 gene positive amplification among age, sex, depth of invasion, clinical stage and vascular infiltration status $(\mathrm{P}>0.05$; Table II).

Association between HER2 gene amplification and survival. Only 42 patients had complete follow-up records out of the total of 70 patients. The follow-up period was 36 months. At the time of the statistics, 22 patients had succumbed to the disease and 20 patients remained alive. Kaplan-Meier univariate survival analysis demonstrated that there was no significant association between HER-2 gene amplification and the survival of ESCC patients ( $\mathrm{P}>0.05$; Fig. 2).

\section{Discussion}

With the development of cancer molecular biology, targeted therapy has entered the clinical treatment stage for various 
Table I. Results of HER-2 and CEP17 by FISH.

\begin{tabular}{|c|c|c|c|c|c|c|c|}
\hline \multirow[b]{2}{*}{ Case } & \multirow[b]{2}{*}{ Age } & \multirow[b]{2}{*}{ Sex } & \multicolumn{4}{|c|}{ Ploidy No. } & \multirow[b]{2}{*}{ FISH } \\
\hline & & & $\begin{array}{c}2 \\
\text { HER-2/CEP17 }\end{array}$ & $\begin{array}{c}3 \\
\text { HER-2/CEP17 }\end{array}$ & $\begin{array}{c}4 \\
\text { HER-2/CEP17 }\end{array}$ & $\begin{array}{c}>15 \\
\text { HER-2/CEP17 }\end{array}$ & \\
\hline 1 & 51 & $\mathrm{M}$ & $62 / 54$ & $38 / 46$ & $0 / 0$ & $0 / 0$ & $\mathrm{~N}$ \\
\hline 2 & 65 & M & $48 / 42$ & $32 / 39$ & $20 / 19$ & $0 / 0$ & $\mathrm{~N}$ \\
\hline 3 & 45 & M & $44 / 44$ & $46 / 34$ & $10 / 22$ & $0 / 0$ & $\mathrm{~N}$ \\
\hline 4 & 54 & $\mathrm{~F}$ & $54 / 38$ & $30 / 32$ & $16 / 30$ & $0 / 0$ & $\mathrm{~N}$ \\
\hline 5 & 50 & $\mathrm{M}$ & $38 / 22$ & $58 / 38$ & $4 / 40$ & $0 / 0$ & $\mathrm{~N}$ \\
\hline 6 & 51 & $\mathrm{~F}$ & $10 / 48$ & $14 / 28$ & $66 / 24$ & $10 / 0$ & $\mathrm{P}$ \\
\hline 7 & 41 & $\mathrm{M}$ & $62 / 48$ & $38 / 28$ & $0 / 24$ & $0 / 0$ & $\mathrm{~N}$ \\
\hline 8 & 63 & $\mathrm{M}$ & $4 / 34$ & $36 / 15$ & $60 / 25$ & $0 / 26$ & $\mathrm{P}$ \\
\hline 9 & 57 & M & $8 / 60$ & $36 / 14$ & $56 / 20$ & $0 / 0$ & $\mathrm{P}$ \\
\hline 10 & 46 & $\mathrm{M}$ & $34 / 22$ & $12 / 60$ & $54 / 18$ & $0 / 0$ & $\mathrm{P}$ \\
\hline 11 & 56 & M & $24 / 46$ & $56 / 20$ & $8 / 32$ & $12 / 2$ & $\mathrm{P}$ \\
\hline 12 & 68 & M & $28 / 38$ & $40 / 26$ & $42 / 36$ & $0 / 0$ & $\mathrm{~N}$ \\
\hline 13 & 63 & $\mathrm{M}$ & $12 / 44$ & $18 / 28$ & $70 / 28$ & $0 / 0$ & $\mathrm{P}$ \\
\hline 14 & 66 & M & $14 / 42$ & $24 / 38$ & $52 / 20$ & $10 / 0$ & $\mathrm{P}$ \\
\hline 15 & 71 & M & $54 / 40$ & $24 / 12$ & $22 / 48$ & $0 / 0$ & $\mathrm{~N}$ \\
\hline 16 & 44 & $\mathrm{M}$ & $28 / 46$ & $34 / 30$ & $38 / 24$ & $0 / 0$ & $\mathrm{~N}$ \\
\hline 17 & 69 & $\mathrm{M}$ & $56 / 22$ & $22 / 18$ & $8 / 56$ & $14 / 4$ & $\mathrm{P}$ \\
\hline 18 & 63 & $\mathrm{M}$ & $48 / 34$ & $14 / 46$ & $38 / 20$ & $0 / 0$ & $\mathrm{~N}$ \\
\hline 19 & 68 & M & $36 / 23$ & $53 / 46$ & $2 / 31$ & $0 / 0$ & $\mathrm{~N}$ \\
\hline 20 & 54 & $\mathrm{M}$ & $5 / 34$ & $35 / 40$ & $60 / 26$ & $0 / 0$ & $\mathrm{P}$ \\
\hline 21 & 59 & $\mathrm{M}$ & $54 / 62$ & $23 / 0$ & $23 / 38$ & $0 / 0$ & $\mathrm{~N}$ \\
\hline 22 & 66 & $\mathrm{M}$ & $7 / 55$ & $50 / 35$ & $33 / 10$ & $10 / 0$ & $\mathrm{P}$ \\
\hline 23 & 64 & $\mathrm{~F}$ & $20 / 10$ & $57 / 50$ & $20 / 40$ & $0 / 0$ & $\mathrm{~N}$ \\
\hline 24 & 50 & $\mathrm{M}$ & $64 / 60$ & $21 / 14$ & $15 / 26$ & $0 / 0$ & $\mathrm{~N}$ \\
\hline 25 & 38 & $\mathrm{~F}$ & $6 / 36$ & $40 / 46$ & $54 / 18$ & $0 / 0$ & $\mathrm{P}$ \\
\hline 26 & 62 & $\mathrm{M}$ & $70 / 70$ & $21 / 0$ & $9 / 22$ & $0 / 8$ & $\mathrm{~N}$ \\
\hline 27 & 57 & $\mathrm{M}$ & $5 / 56$ & $55 / 22$ & $40 / 12$ & $0 / 10$ & $\mathrm{P}$ \\
\hline 28 & 67 & $\mathrm{~F}$ & $12 / 41$ & $40 / 45$ & $34 / 14$ & $14 / 0$ & $\mathrm{P}$ \\
\hline 29 & 52 & $\mathrm{M}$ & $64 / 49$ & $24 / 19$ & $12 / 32$ & $0 / 0$ & $\mathrm{~N}$ \\
\hline 30 & 47 & $\mathrm{M}$ & $10 / 23$ & $49 / 67$ & $38 / 10$ & $0 / 0$ & $\mathrm{P}$ \\
\hline 31 & 50 & $\mathrm{M}$ & $70 / 60$ & $24 / 16$ & $6 / 24$ & $0 / 0$ & $\mathrm{~N}$ \\
\hline 32 & 52 & $\mathrm{M}$ & $15 / 34$ & $31 / 40$ & $44 / 10$ & $0 / 0$ & $\mathrm{P}$ \\
\hline 33 & 49 & $\mathrm{M}$ & $10 / 30$ & $43 / 56$ & $35 / 8$ & $12 / 2$ & $\mathrm{P}$ \\
\hline 34 & 63 & $\mathrm{M}$ & $63 / 49$ & $24 / 21$ & $13 / 30$ & $0 / 0$ & $\mathrm{~N}$ \\
\hline 35 & 57 & $\mathrm{M}$ & $5 / 30$ & $39 / 61$ & $45 / 9$ & $11 / 0$ & $\mathrm{P}$ \\
\hline 36 & 62 & $\mathrm{M}$ & $58 / 66$ & $19 / 3$ & $25 / 31$ & $0 / 0$ & $\mathrm{~N}$ \\
\hline 37 & 57 & $\mathrm{M}$ & $41 / 50$ & $36 / 16$ & $23 / 34$ & $0 / 0$ & $\mathrm{~N}$ \\
\hline 38 & 57 & $\mathrm{~F}$ & $45 / 59$ & $25 / 13$ & $20 / 28$ & $0 / 0$ & $\mathrm{~N}$ \\
\hline 39 & 62 & $\mathrm{~F}$ & $58 / 55$ & $14 / 21$ & $28 / 24$ & $0 / 0$ & $\mathrm{~N}$ \\
\hline 40 & 69 & $\mathrm{~F}$ & 4/19 & $56 / 71$ & $40 / 10$ & $10 / 0$ & $\mathrm{P}$ \\
\hline 41 & 45 & $\mathrm{M}$ & $6 / 47$ & $36 / 28$ & $58 / 20$ & $0 / 5$ & $\mathrm{P}$ \\
\hline 42 & 43 & $\mathrm{M}$ & $67 / 48$ & $10 / 0$ & $16 / 21$ & $7 / 8$ & $\mathrm{~N}$ \\
\hline 43 & 58 & $\mathrm{~F}$ & $4 / 20$ & $30 / 54$ & $54 / 14$ & $12 / 0$ & $\mathrm{P}$ \\
\hline 44 & 66 & $\mathrm{M}$ & $69 / 50$ & $24 / 10$ & $6 / 24$ & $1 / 16$ & $\mathrm{~N}$ \\
\hline 45 & 57 & $\mathrm{M}$ & $64 / 49$ & $20 / 19$ & $16 / 32$ & $0 / 0$ & $\mathrm{~N}$ \\
\hline 46 & 79 & $\mathrm{M}$ & $12 / 54$ & $30 / 18$ & $48 / 18$ & $10 / 0$ & $\mathrm{P}$ \\
\hline 47 & 57 & $\mathrm{M}$ & $12 / 40$ & $22 / 38$ & $54 / 20$ & $12 / 2$ & $\mathrm{P}$ \\
\hline 48 & 54 & $\mathrm{~F}$ & $44 / 38$ & $34 / 16$ & $22 / 46$ & $0 / 0$ & $\mathrm{~N}$ \\
\hline 49 & 61 & $\mathrm{~F}$ & $58 / 44$ & $18 / 32$ & $24 / 24$ & $0 / 0$ & $\mathrm{~N}$ \\
\hline 50 & 51 & $\mathrm{M}$ & $12 / 28$ & $16 / 44$ & $68 / 28$ & $6 / 0$ & $\mathrm{P}$ \\
\hline
\end{tabular}


Table I. Continued.

Ploidy no.

\begin{tabular}{|c|c|c|c|c|c|c|c|}
\hline \multirow[b]{2}{*}{ Case } & \multirow[b]{2}{*}{ Age } & \multirow[b]{2}{*}{ Sex } & \multicolumn{4}{|c|}{ Ploidy no. } & \multirow[b]{2}{*}{ FISH } \\
\hline & & & $\begin{array}{c}2 \\
\text { HER-2/CEP17 }\end{array}$ & $\begin{array}{c}3 \\
\text { HER-2/CEP17 }\end{array}$ & $\begin{array}{c}4 \\
\text { HER-2/CEP17 }\end{array}$ & $\begin{array}{c}>15 \\
\text { HER-2/CEP17 }\end{array}$ & \\
\hline 51 & 63 & M & $55 / 48$ & $22 / 38$ & $23 / 14$ & $0 / 0$ & $\mathrm{~N}$ \\
\hline 52 & 69 & M & $18 / 40$ & $10 / 32$ & $72 / 28$ & $0 / 0$ & $\mathrm{P}$ \\
\hline 53 & 73 & M & $5 / 14$ & $8 / 24$ & $76 / 22$ & $11 / 1$ & $\mathrm{P}$ \\
\hline 54 & 51 & M & $12 / 60$ & $34 / 20$ & $54 / 20$ & $0 / 0$ & $\mathrm{P}$ \\
\hline 55 & 68 & M & $16 / 21$ & $24 / 58$ & $48 / 18$ & $12 / 3$ & $\mathrm{P}$ \\
\hline 56 & 66 & M & $16 / 50$ & $18 / 26$ & $66 / 24$ & $0 / 0$ & $\mathrm{P}$ \\
\hline 57 & 63 & M & $21 / 30$ & $22 / 58$ & $46 / 12$ & $11 / 0$ & $\mathrm{P}$ \\
\hline 58 & 57 & $\mathrm{~F}$ & $8 / 36$ & $20 / 41$ & $58 / 20$ & $14 / 3$ & $\mathrm{P}$ \\
\hline 59 & 32 & M & $18 / 28$ & $12 / 48$ & $60 / 24$ & $10 / 0$ & $\mathrm{P}$ \\
\hline 60 & 56 & M & $22 / 44$ & $24 / 40$ & $54 / 16$ & $0 / 0$ & $\mathrm{P}$ \\
\hline 61 & 66 & $\mathrm{~F}$ & $16 / 30$ & $22 / 46$ & $62 / 24$ & $0 / 0$ & $\mathrm{P}$ \\
\hline 62 & 61 & $\mathrm{~F}$ & $16 / 34$ & $20 / 44$ & $52 / 22$ & $12 / 0$ & $\mathrm{P}$ \\
\hline 63 & 64 & M & $40 / 32$ & $36 / 48$ & $24 / 20$ & $0 / 0$ & $\mathrm{~N}$ \\
\hline 64 & 77 & $\mathrm{~F}$ & $56 / 60$ & $24 / 30$ & $20 / 10$ & $0 / 0$ & $\mathrm{~N}$ \\
\hline 65 & 53 & M & $62 / 58$ & $38 / 42$ & $0 / 0$ & $0 / 0$ & $\mathrm{~N}$ \\
\hline 66 & 49 & $\mathrm{~F}$ & $21 / 32$ & $16 / 48$ & $52 / 20$ & $10 / 0$ & $\mathrm{P}$ \\
\hline 67 & 63 & M & $33 / 40$ & $6 / 38$ & $61 / 22$ & 0 & $\mathrm{P}$ \\
\hline 68 & 52 & M & $56 / 48$ & $34 / 44$ & $10 / 8$ & $0 / 0$ & $\mathrm{~N}$ \\
\hline 69 & 75 & M & $12 / 26$ & $16 / 29$ & $72 / 30$ & $0 / 5$ & $\mathrm{P}$ \\
\hline 70 & 70 & M & $58 / 42$ & $36 / 40$ & $6 / 18$ & $0 / 0$ & $\mathrm{~N}$ \\
\hline
\end{tabular}

FISH, fluorescence in situ hybridization; P, Positive amplification; N, No amplification.
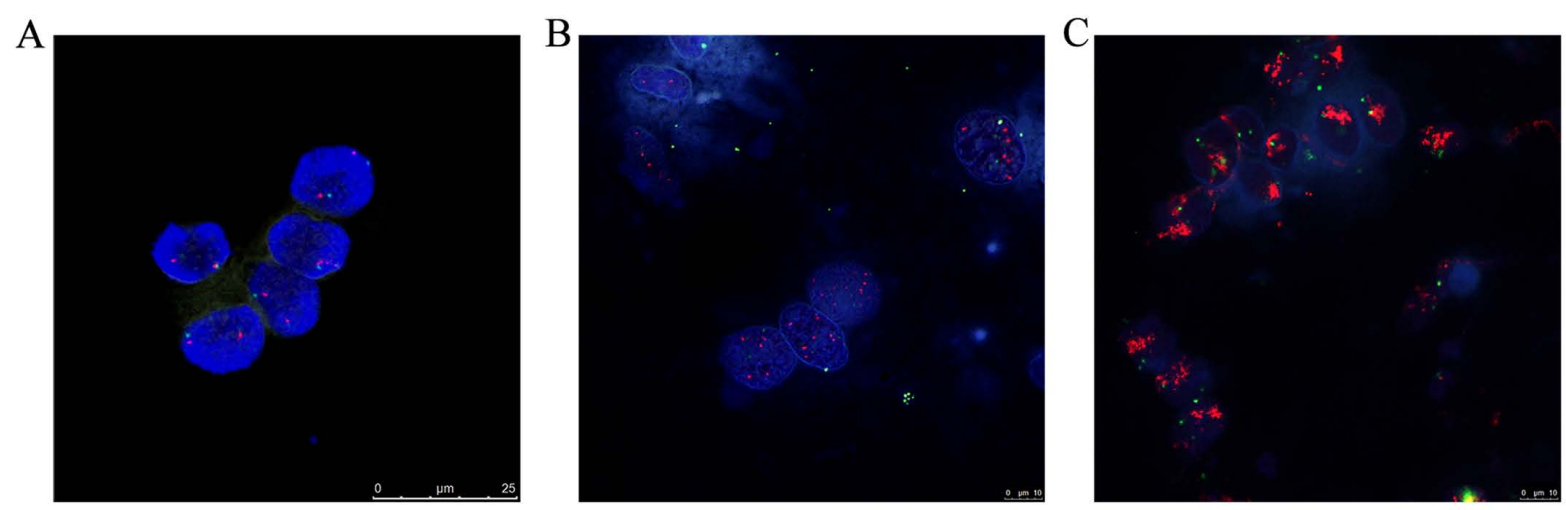

Figure 1. Fluorescent in-situ hybridization detection of HER-2 gene amplification in esophageal cancer tissues. (A) Tissue exhibiting a normal pattern of HER-2/neu gene ( 2 red spots) and chromosome 17 probe ( 2 green spots). (B) Tissue demonstrating amplified HER-2/neu gene (amplification of the ratio between HER-2/neu signals and CEP17 signals, >2.2). (C) Tissue demonstrating HER-2/neu gene amplification (>15 HER-2/neu signals and multiple CEP17 signals in $>10 \%$ of the tumor cell nucleus).

cancer types, to provide an effective treatment for patients with malignant tumors, including esophageal cancer (12-14). A large number of clinical studies have demonstrated that HER-2 is a therapeutic target for breast cancer and the efficacy of herceptin for treating patients with HER-2-positive breast cancer is significantly better than conventional chemotherapy, and this consensus has been reached in the treatment of breast cancer (15).

Studies have shown that the HER-2 gene is associated with the histological types, lymph node metastasis and prognosis of various malignant tumors (16). In the past few years, a large number of studies on HER-2 gene amplification or protein overexpression in epithelial malignant tumors such as gastric cancer, lung cancer and breast cancer have been published (17-20). However, there are few reported studies examining HER-2 gene amplification in esophageal cancer. In the present study, HER-2 amplification was examined in ESCC specimens of Kazakh populations, then the association between HER-2 amplification and clinicopathological 
Table II. Relationship between HER-2 gene amplification and clinicopathological characteristics of patients with esophageal squamous cell carcinoma.

\begin{tabular}{|c|c|c|c|c|c|}
\hline \multirow[b]{2}{*}{ Variable } & \multirow[b]{2}{*}{ Case } & \multicolumn{2}{|c|}{ HER-2 amplification, n (\%) } & \multirow[b]{2}{*}{$\chi^{2}$} & \multirow[b]{2}{*}{$\mathrm{P}$-value } \\
\hline & & Positive & Negative & & \\
\hline Sex & & & & 0.032 & 0.544 \\
\hline Male & 54 & $29(54)$ & $25(46)$ & & \\
\hline Female & 16 & $9(56)$ & $7(44)$ & & \\
\hline Age (years) & & & & 0.048 & 0.508 \\
\hline$<60$ & 36 & $20(56)$ & $16(44)$ & & \\
\hline$\geq 60$ & 34 & $18(53)$ & $16(47)$ & & \\
\hline Differentiation & & & & 16.925 & $<0.001$ \\
\hline Well & 14 & $2(14)$ & $12(86)$ & & \\
\hline Moderate & 39 & $21(54)$ & $18(46)$ & & \\
\hline Poor & 17 & $15(88)$ & $2(12)$ & & \\
\hline Depth of invasion & & & & 1.228 & 0.193 \\
\hline $\mathrm{T}_{1-2}$ & 30 & $14(47)$ & $16(53)$ & & \\
\hline $\mathrm{T}_{3-4}$ & 40 & $24(60)$ & $16(40)$ & & \\
\hline Lymph node metastasis & & & & 6.557 & 0.010 \\
\hline Yes & 41 & $17(41)$ & $24(59)$ & & \\
\hline No & 29 & $21(72)$ & $8(28)$ & & \\
\hline pTNM & & & & 2.256 & 0.105 \\
\hline $\mathrm{I}, \mathrm{II}$ & 46 & $22(48)$ & $24(52)$ & & \\
\hline III, IV & 24 & $16(67)$ & $8(33)$ & & \\
\hline
\end{tabular}

pTNM, pathological stage.

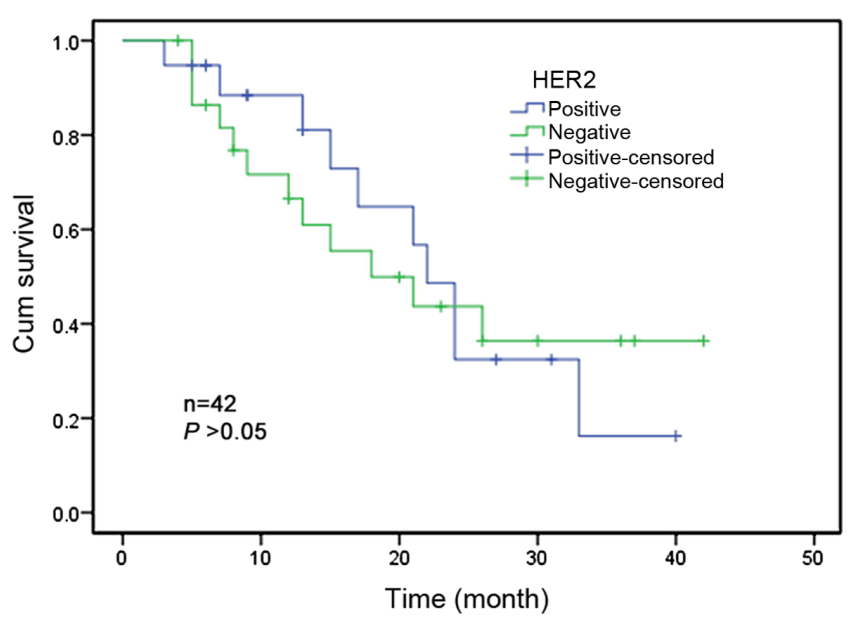

Figure 2. Relationship between HER-2 gene amplification and survival.

characteristics of ESCC was analyzed. The aim of the study was to provide theoretical evidence for the targeted therapy of esophageal cancer.

Among the studies of esophageal cancer in different regions and ethnicities, the HER2 gene amplification rates have been recorded as $6.5-30 \%$ (21-22). In the present study, the HER-2 gene amplification rate was $54.2 \%$ in Kazakh patients, which was significantly higher than that reported in other nationalities. Whether this is related to the life habits of Kazakhs, for example heavy drinking, smoking, eating large quantities of smoked horse meat, high-salt diet, low vitamin consumption or other esophageal cancer-inducing factors or ethnicity is unclear, and this needs further study for verification.

There are also different conclusions about the association between HER-2 gene amplification and clinicopathological characteristics of ESCC. By using FISH, Reichelt et al (23) detected that the HER-2 gene amplification levels in ESCC had no association with clinicopathological features. Zhan et al (24) reported that the HER-2 amplification was related to the differentiation and staging of cancer tissues. The results of the present study showed that there were significant differences in the degree of differentiations and lymph node metastasis in ESCC. Niemiec et al found that HER-2 promotes the infiltration and/or metastasis of tumor cells by increasing the secretion of matrix metalloproteinase and changing the tissue structure (25). The current study suggests that the HER-2 gene was closely associated with the occurrence and development of esophageal cancer and that HER-2 gene expression indicated poor prognosis of esophageal cancer to some extent. However, the Kazakh people are a nomadic people, most of them living in mountain areas and without a stable phone number, so the proportion of lost follow-up is a little bit high, even though the follow-up rate was $60 \%$, so these conclusions need to be further confirmed by larger samples study. Besides, there was no significant association 
between HER-2 gene amplification and clinicopathological parameters such as sex, age, depth of invasion and clinical stage. In addition, the amplification of the HER-2 gene was not related to the survival period of patients, and this result may be due to such factors including the limited numbers of samples, different geographical regions and targeted population. The amplification of the HER-2 gene may be associated with the following factors: i) The number of follow-up patients is small; ii) The target population of the living area and the ethnicity varied; iii) The regional economic development level, medical conditions, diagnosis, treatment, patients' education level and positive treatment views.

In conclusion, the amplification rate of HER-2 in patients of Kazakh nationality with ESCC is significantly higher than that of other nationalities, and it is related to the degree of cancer differentiation and lymph node metastasis. The HER-2 amplification rate may have potential clinical significance in the prognostic evaluation of esophageal cancer, and it can also be used as a potential target therapy. But there are still some limitations in our study, because the manuscript was focus at the association between HER2 amplification and clinicopathological parameters and prognosis of esophageal cancer, and the association between HER2 expression and esophageal cancer pathological parameters has been reported in many literatures, so we only analyze the amplification level under FISH detection. However, the evidence behind HER-2 amplification as an independent prognostic factor for patients with esophageal cancer is still insufficient, this needs to be further validated by large-sample, multi-center and long-term follow-up studies.

\section{Acknowledgements}

Not applicable.

\section{Funding}

The present study was funded by the Natural Science Foundation of Xinjiang Uygur Autonomous Region (grant no. 2016D01C264).

\section{Availability of data and materials}

The datasets used and/or analyzed during the current study are available from the corresponding author on reasonable request.

\section{Authors' contributions}

AM and EA was designed the current study, performed the experiments, drafted the manuscript and collected various clinical data, including clinicopathological and patient follow-up data. JA was analyzed and interpreted the data, performed statistical analysis and assisted with the experiments. $\mathrm{MN}$ and ZL provided study materials, revised the manuscript critically and designed the experiments of the current study. All authors read and approved the final manuscript.

\section{Ethics approval and consent to participate}

All experiments were approved by The Ethics Committee of The First Affiliated Hospital of Xinjiang Medical University, and written informed consent was obtained from all participants.

\section{Patient consent for publication}

Not applicable.

\section{Competing interests}

The authors declare that they have no competing interests.

\section{References}

1. Zheng R, Zeng H, Zhang S and Chen W: Estimates of cancer incidence and mortality in China, 2013. Chin J Cancer 36: 66, 2017.

2. Gupta B and Kumar N: Worldwide incidence, mortality and time trends for cancer of the oesophagus. EurJ Cancer Prev 26: 107-118, 2017.

3. Zhou YX, Zhou KM, Liu Q, Wang H, Wang W, Shi Y and Ma YQ: The effect of glutl and c-myc on prognosis in esophageal squamous cell carcinoma of Kazakh and Han patients. Future Oncol 14: 1801-1815, 2018.

4. Kim T, Grobmyer SR, Smith R, Ben-David K, Ang D, Vogel SB and Hochwald SN: Esophageal cancer: The five year survivors. J Surg Oncol 103: 179-183, 2011.

5. Sagara Y, Kamada Y, Yamamoto Y, Tanaka M, Kubo M, Yamaguchi R, Nishimura R and Mitsuyama S: Study on the state of implementation of HER2 testing and positive ratios in patients with breast cancer in the Kyushu-Okinawa region of Japan. Breast Cancer 19: 315-320, 2012

6. Rosińska, A, Rosiński G and Hołubowicz R: Advdnces on the HER-2/neu and oncotherapy. Acta Academiae Medicinae Cpaf 62, 2008.

7. Halling KC and Kipp BR: Fluorescence in situ hybridization indiagnostic cytology. Surg Oncol Clin N Am 18: 411-422, 2009.

8. Fritcher EG, Brankley SM, Kipp BR, Voss JS, Campion MB, Morrison LE, Legator MS, Lutzke LS, Wang KK, Sebo TJ and Halling KC: A comparison of conventional cytology,DNA ploidy analysis, and fluorescence in situ hybridization for the detection of dysplasia and adenocarcinoma in patients with barrett's esophagus. Hum Pathol 39: 1128-1135, 2008.

9. Dietel M, Ellis IO, Höfler H, Kreipe H, Moch H, Dankof A, Kölble K and Kristiansen G: Comparison of automated silver enhanced in situ hybridisation (SISH) and fluorescence ISH (FISH) for the validation ofHER2gene status in breast carcinoma according to the guidelines of the American society of clinical oncology and the college of American pathologists. Virchows Arch 451: 19-25, 2007.

10. Amin MB, Edge S, Greene F, (eds), et al: AJCC Esophageal and esophagogastric junction. AJCC Cancer Staging Manual. 8th edition. NewYork, Springer; pp185-202: 2017.

11. Huang JX, Zhao K, Lin M, Wang Q, Xiao W, Lin MS, Yu H, Chen P and Qian RY: HER2 gene amplification in esophageal squamous cell carcinoma is less than in gastroesophageal junction and gastric adenocarcinoma. Oncol Lett 6: 13-18, 2013.

12. Shroff GS, De Groot PM, Papadimitrakopoulou VA, Truong MT and Carter BW: Targeted therapy and immunotherapy in the treatment of non-small cell lung cancer. Radiol Clin North Am 56: 485-495, 2018.

13. Alvarez RH, Valero V and Hortobagyi GN: Emerging targeted therapies for breast cancer. J Clin Oncol 28: 3366-3379, 2010.

14. Lin CY, Yang SJ, Peng CL and Shieh MJ: PanitumumabConjugated and platinum-cored $\mathrm{pH}$-sensitive apoferritin nanocages for colorectal cancer-targeted therapy. ACS Appl Mater Interfaces 21: 6096-6106, 2018.

15. Vu T, Sliwkowski MX and Claret FX: Personalized drug combinations to overcome trastuzumab resistance in HER2-positive breast cancer. Biochim Biophys Acta 1846: 353-365, 2014.

16. Gutierrez CC and Schiff RR: HER2: Biology, detection, and clinical implications. Arch Pathol Lab Med 135: 55-62, 2011.

17. Yan SY, Hu Y, Fan JG, Tao GQ, Lu YM, Cai X, Yu BH and Du YQ: Clinicopathologic significance of HER-2/neu protein expression and gene amplification in gastric carcinoma. World J Gastroenterol 17: 1501-1506, 2011. 
18. Li HH, Ma F, Zeng X, Wang JY, Yuan P, Fan Y and Xu BH: Comparison of fluorescence in situ hybridization and immunohistochemistry assessment for Her-2 status in breast cancer and its relationship to clinicopathological characteristics. Zhonghua Yi Xue Za Zhi 91: 76-80, 2013 (In Chinese).

19. Koo JS and Kim SH: EGFR and HER-2 status of non-small cell lung cancer brain metastasis and corresponding primary tumor. Neoplasma 58: 27-34, 2011.

20. Bouché $\mathrm{O}$ and Penaultllorca F: HER-2 and gastric cancer: A novel therapeutic target for trastuzumab. Bull Cancer 97: 1429-1440, 2010 (In French).

21. Sato-Kuwabara Y, Neves JI, Fregnani JH, Sallum RA and Soares FA: Evaluation of gene amplification and protein expression of HER-2/neu in esophageal squamous cell carcinoma using fluorescence in situ hybridization (FISH) and immunohistochemistr. BMC Cancer 7: 9, 2009.

22. Wei Q, Chen L, Sheng L, Nordgren H, Wester K and Carlsson J: EGFR, HER-2 and HER3 expression in esophageal primary tumours and corresponding metastases. Int J Oncol 31: 493-499, 2007.
23. Reichelt U, Duesedau P, Tsourlakis MC, Quaas A, Link BC, Schurr PG, Kaifi JT, Gros SJ, Yekebas EF, Marx A, et al: Frequent homogeneous HER-2 amplification in primary and metastatic adenocarcinoma of the esophagus. Mod Pathol 20: 120-129, 2007

24. Zhan N, Dong WG, Tang YF, Wang ZS and Xiong CL: Analysis of HER-2 gene amplification and protein expression in esophageal squamous cell carcinoma. Med Oncol 29: 933-940, 2012.

25. Niemiec JA, Adamczyk A, Małecki K, Majchrzyk K and Ryś J: Relationships between immunophenotype, Ki-67 index, microvascular density, Ep-CAM/P-cadherin, and MMP-2 expression in early-stage invasive ductal breast cancer. Appl Immunohistochem Mol Morphol 20: 550-560, 2012.

(i) () (9) This work is licensed under a Creative Commons Attribution-NonCommercial-NoDerivatives 4.0 International (CC BY-NC-ND 4.0) License. 